\title{
In vitro antitumor activity of chemical constituents of EtOAc extract from Artemisa gmelinii.
}

\author{
Yu Hua, Qinghu Wang*, Biligetu Pa, Wenqiang Bao, Junsheng Hao, Jingjing Han \\ College of Traditional Mongolian Medicine, Inner Mongolia University for Nationalities, No. 996 Xilamulun District, \\ Tongliao, PR China
}

\begin{abstract}
Objective: To investigate the chemical composition of EtOAc extract from Artemisa gmelinii Web. ex Stechm. (A. gmelinii) and evaluate their in vitro antitumor activity.

Methods: The EtOAc crude extract from the aerial parts of $\boldsymbol{A}$. gmelinii was isolated by chromatography and the structures of the isolated compounds were elucidated based on spectral analysis. All the isolated compounds were investigated for their in vitro activity against four human cancer cell lines by SRB (Sulforhodamine B) assay.

Main findings: Eight compounds, namely ameliaroside (1), annphenone (2), 6, 8-dimethoxycoumarin-7O- $\beta$-D-glucuronide (3) 6-methoxycoumarin-7-O- $\beta$-D-glucuronide (4), sacroflavone A (5), sacroflavone B (6), sacric acid A (7) and sacric acid B (8) were isolated from the EtOAc extract from $A$. gmelinii. Compounds 3-6 have certain activity against these tested human cancer cell lines. Among of them, compound $5\left(\mathrm{IC}_{50}: 5.03-6.78 \mu \mathrm{mol} / \mathrm{L}\right)$ was found more potent than those of the reference Etoposide $\left(\mathrm{IC}_{50}:>50 \mu \mathrm{mol} / \mathrm{L}\right)$ against Hela and $\mathrm{MKN}-45$.

Conclusion: Compounds 1-8 are isolated from this plant for the first time. Compound 5 (IC I0: 5.03-6.78 $\mu \mathrm{mol} / \mathrm{L})$ was found more potent than those of the reference Etoposide $\left(\mathrm{IC}_{50}:>50 \mu \mathrm{mol} / \mathrm{L}\right)$ against Hela and MKN-45. Compound 5 have good antitumor effect which may be used as potential antitumor agent.
\end{abstract}

Keywords: Artemisa gmelinii, Chemical compositions, sacroflavone A, Antitumor activity. Abbreviations: SRB: Sulforhodamine B; HPLC: High-Performance Liquid Chromatography; HMBC: ${ }^{1} \mathrm{H}$ Detected Heteronuclear Multiple Bond Correlation.

Accepted on May 31, 2018

\section{Introduction}

Tumor is the most common and frequently occurring diseases, of which malignant carcinoma is one of the most serious diseases that endanger human health [1-3]. It is estimated that annual tumor cases will rise from 14 million in 2012 to 22 million within the next two decades [4-6]. Today, although the synthetic antitumor drugs are dominating the market, their negative side-effects and the risk of resistance remain a pressing matter in their clinical use. These issues drive the research and development of herbal medicines, which have made a comeback to improve our basic health needs. Many medicinal plants such as Radix ophiopogonis, Panax quinquefolium, Ganoderma lucidum Karst and Angelica sinensis, have been shown to exhibit potent antitumor effects [7-10].

Artemisa gmelinii, family composite, is widely distributed in Inner Mongolia of China [11]. Artemisa gmelinii (aerial parts) are used as a characteristic medicine in Mongolian folk to treat cancer and its related diseases. It is widely used in Mongolian as a substitute of the material medica, Artemisa sacrorum
Ledeb., which is used in treatment of infantile convulsion, hepatitis, appendicitis and trauma. The secondary metabolites including flavonoids [12] and sesquiterpenes [13] have been isolated from the aerial parts of Artemisa gmelinii. However, there is few reported scientific study to support these claimed therapeutic and medicinal effects. In our previous pharmacological studies [14] on this plant showed that the EtOAc extracts of Artemisa gmelinii had anti-tumour activity, which urges us to study the EtOAc extracts from Artemisa gmelinii. In our phytochemical investigation, eight compounds were isolated, such as ameliaroside (1), annphenone (2), 6, 8dimethoxycoumarin-7-O- $\beta$-D-glucuronide (3) 6methoxycoumarin-7-O- $\beta$-D-glucuronide (4), sacroflavone A (5), sacroflavone B (6), sacric acid A (7) and sacric acid B (8), whose structures are shown in Figure 1.

For searching more potent antitumor agents, we centered our attention on the isolated compounds from the EtOAc extracts of Artemisa gmelinii. All the isolated compounds were investigated for their in vitro activity against four human cancer cell lines, including HepG2 (liver carcinoma), Hela (cervical cancer), MCF-7 (breast cancer) and MKN-45 (gastric 
cancer) by SRB. This paper describes the antitumor activity and the chemical composition from the EtOAc extract of Artemisa gmelinii.

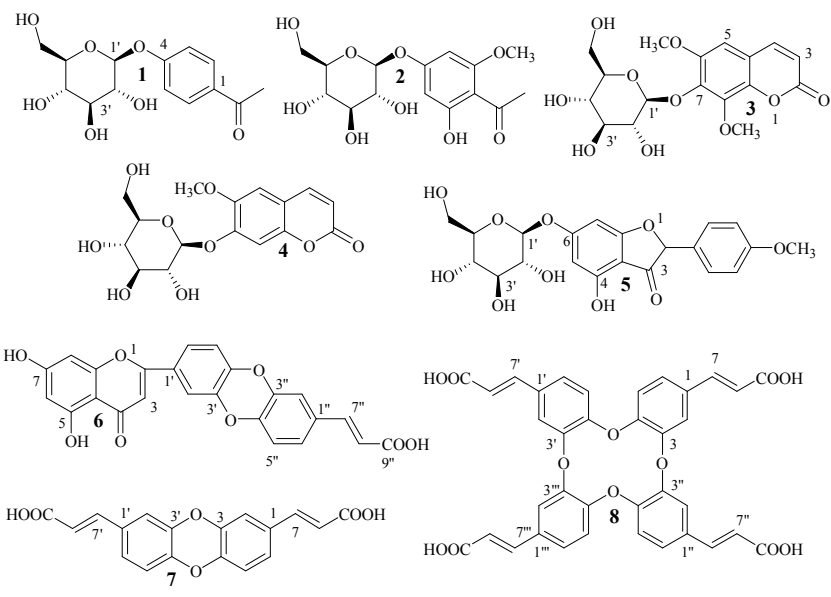

Figure 1. Structures of compounds 1-8.

\section{Materials and Methods}

\section{General experimental procedures}

NMR experiments were performed on a Bruker Avance Ш-500 NMR spectrometer (Bruker, Germany). Semipreparative HPLC was performed by using a Japanese liquid chromatograph equipped with an EZ0566 column. Column chromatography was performed by using silica gel (200-300 mesh, Marine Chemical Factory, Qingdao, China). High-Performance Liquid Chromatography (HPLC)-grade acetonitrile was purchased from Merck (Darmstadt, Germany). All other chemicals and reagents were analytical grade.

\section{Plant material}

Artemisa gmelinii (aerial parts) were collected in Humeng, Inner Mongolia, China, in July 2016. The plant material was identified by Prof. Wuxiangjie (Inner Mongolia University for Nationalities) and a voucher specimen was stored in the Mongolian Medicine Research Center, Inner Mongolia University for Nationalities.

\section{Extraction and isolation}

The air-dried and powdered aerial parts of Artemisa gmelinii $(2.0 \mathrm{Kg})$ were extracted twice with EtOAc $(20 \mathrm{~L})$ at $80^{\circ} \mathrm{C}$ for 4 $\mathrm{h}$ after extracting with $\mathrm{CHCl} 3(10 \mathrm{~L})$. The combined EtOAc extracts were concentrated to a residue (180 g, yield 9.0\%) under reduced pressure. The EtOAc extract (180.0 g) was isolated by column chromatography on silica gel and gradiently eluted with $\mathrm{CHCl}_{3}-\mathrm{MeOH}(50: 1$ to $10: 1)$ to give 3 fractions (Fr. $\left.\mathrm{C}_{1-3}\right)$. Fr. $\mathrm{C} 1$ ((15 g, $\left.\mathrm{CHCl}_{3}-\mathrm{MeOH}(30: 1)\right)$ eluate was further chromatographed on Sephadex LH-20 column eluting with $\mathrm{MeOH}$, and then separated by semipreparative HPLC $\left(\mathrm{CH}_{3} \mathrm{CN}-\mathrm{H}_{2} \mathrm{O}, 59: 41\right)$ yielding 1 (51 mg), 2 (75 mg), 3 $(67 \mathrm{mg}), 4(48 \mathrm{mg})$ and $5(92 \mathrm{mg})$. Fr. $\mathrm{C}_{3}\left(21 \mathrm{~g}, \mathrm{CHCl}_{3}-\mathrm{MeOH}\right.$ $(10: 1)$ eluate) was further separated by semipreparative HPLC
$\left(\mathrm{CH}_{3} \mathrm{CN}-\mathrm{H}_{2} \mathrm{O}, 41: 59\right)$ to yield $6(32 \mathrm{mg}), 7(29 \mathrm{mg})$ and $8(45$ $\mathrm{mg})$.

\section{Anti-tumor activities}

All the isolated compounds were investigated for their in vitro activity against four human cancer cell lines, including HepG2 (liver carcinoma), Hela (cervical cancer), MCF-7 (breast cancer) and MKN-45 (gastric cancer) by SRB assay [15].

\section{Results and Discussion}

From the EtOAc extract of Artemisa gmelinii, eight compounds including ameliaroside (1), annphenone (2), 6, 8dimethoxycoumarin-7-O- $\beta$-D-glucuronide

(3) 6methoxycoumarin-7-O- $\beta$-D-glucuronide (4), sacroflavone A (5), sacroflavone B (6), sacric acid A (7) and sacric acid B (8) were obtained from this plant for the first time. Their structures were elucidated on the basis of comparing their NMR data with those reported in the literature [16-22].

According to the biological evaluation results shown in Table 1 , the compounds $1-8\left(\mathrm{IC}_{50}: 10.14-45.23 \mu \mathrm{mol} / \mathrm{L}\right)$ have certain activity against HepG2 and MCF-7. Among of them, compounds 3-6 have certain activity against these tested human cancer cell lines. All of them $\left(\mathrm{IC}_{50}: 5.03-35.56 \mu \mathrm{mol} / \mathrm{L}\right)$ are more active than Etoposide (IC50: $>50 \mathrm{~m} \mathrm{~mol} / \mathrm{L}$ ) against Hela and MKN-45. Moreover, compound 5 was found to have potent activity $\left(\mathrm{IC}_{50}: 5.03-13.66 \mu \mathrm{mol} / \mathrm{L}\right)$ against all of the tested cell lines and was $\mathrm{IC}_{50}(5.03-6.78 \mu \mathrm{mol} / \mathrm{L})$ found more potent than those of the reference against Hela and MKN-45.

Table 1. In vitro activity of compounds 1-8 against four cell lines.

\begin{tabular}{lllll}
\hline \multirow{2}{*}{ Compounds } & \multicolumn{3}{l}{$\mathrm{IC}_{50}{ }^{\mathrm{a}}(\boldsymbol{\mu \mathrm { mol } / \mathrm { L } )}$} & \\
\cline { 2 - 5 } & HepG2 & Hela & MCF-7 & MKN-45 \\
\hline 1 & 45.23 & 38.00 & 40.12 & $>50$ \\
\hline 2 & 43.15 & 36.45 & 38.45 & $>50$ \\
\hline 3 & 23.07 & 20.12 & 35.56 & 31.46 \\
\hline 4 & 20.19 & 18.99 & 33.36 & 29.65 \\
\hline 5 & 13.66 & 6.78 & 10.14 & 5.03 \\
\hline 7 & 16.55 & 21.54 & 26.66 & 32.47 \\
\hline 8 & 19.32 & 38.22 & 25.37 & $>50$ \\
\hline Etoposide & 17.88 & $>50$ & 23.22 & $>50$ \\
\hline
\end{tabular}

${ }^{a} C_{50}$ values were presented as the concentration of drug inhibition $50 \%$ cell growth and determined by at least three separate tests and reported.

Compound 5 is a derivative of diphenylethene. Diphenylethene is a group of natural organic compounds with a $\mathrm{C}_{6}-\mathrm{C}_{2}-\mathrm{C}_{6}$ unit in the parent nucleus, which have a variety of biological activities, such as anti-tumor, antihypertensive, ester, antiplatelet aggregation, antibacterial and so on. For example, resveratrol is a widely known natural product, which exhibited 
significant pharmacological activities [23-26] and considered a plant antitoxin. The structure of compound 5 can be regarded as the oxidized and cyclization of the vinyl group $\left(\mathrm{C}_{2}\right)$ in diphenylethene. The structural characteristics of compound 5 may be the reason why compound 5 have good antitumor effect. In addition, the type of sugar linkage with the aglycone should be an important factor for the antitumor activity of compound 5 .

\section{Acknowledgement}

This work was supported by the National Natural Science Foundation of China (No. 81660698) and the Science and Technology Major Project of Inner Mongolia Mongolian medicine in China (No. GCY20150712).

\section{Conflict of Interest}

The authors declare no financial or commercial conflicts of interest.

\section{References}

1. Lv K, Wang LL, Zhou XB. Synthesis and in vitro antitumor activity of 1-(3-dimethylamino)propylindolin-2-one derivatives. Med Chem Res 2013; 22: $1723-1729$.

2. Gluckman PD. Epigenetic mechanisms that underpin metabolic and cardiovascular diseases. Nat Rev Endocrinol 2009; 5: 401-408.

3. Gozuacik D, Kimchi A. Autophagy as a cell death and tumor suppressor mechanism. Oncogene 2004; 23: 2891-2906.

4. Jemal A, Bray F, Center, MM. Global cancer statistics. Cancer J Clin 2011; 61: 69-90.

5. Zhou Q, Lin GZ, Li K, Dong H, Liu XY, Shen JC. Cancer incidence from 2004 to 2009 in Guangzhou. Chin J Caner Prev Treat 2013; 20: 972-976.

6. Jia XD, Wang S, Wang MH, Liu ML, Xia GM, Liu XJ, Chai Y, He HW. Synthesis and in vitro antitumor activity of novel naphthyridinone derivatives. Chin Chem Lett 2017; 28: 235-239.

7. Lin SS, Fan W, Sun L, Li FF, Zhao RP, Zhang LY, Yu BY, Yuan ST. The saponin DT-13 inhibits gastric cancer cell migration through down-regulation of CCR5-CCL5 axis. Chin J Nat Med. 2014; 12: 833-840.

8. Schmitz I, Kirchhoff S, Krammer PH. Regulation of death receptor-mediated apoptosis pathways. Int J Biochem Cell Biol 2000; 32: 1123-1136.

9. Adams JM. Ways of dying: multiple pathways to apoptosis. Genes Devel 2003; 17: 2481-2495.

10. Klionsky DJ, Ernr SD. Autophagy as a regulated pathway of cellular degradation. Science 2000; 290: 1717-1721.

11. Wang XX, Jin GZ. Review on research of the chemical constituents and pharmacological activities of Artemisia sacrorum. J Chin Med Mat 2010; 33: 831-834.
12. Zeng WZ, Sheng Q, Zhang QY, Liang H. Flavonoids from Artemisia gmelinii Web. ex Stechm. J Chin Pharm Sci 2014; 23: 496-499.

13. Zeng WZ, Sheng Q, Zhang QY, Liang H. Two new oplopane sesquiterpenes from Artemisia gmelinii Web. ex Stechm. Chin Chem Lett 2014; 25: 1153-1156.

14. Wang QH, Wu RJ, Qi GQ, Wu JS, Dai NYT, Han NRCKT. Chemical Constituents of Artemisa gmelinii. Chin Pharm J 2015; 50: 1380-1383.

15. Skehan P, Storeng R, Scudiero D. New colorimetric cytotoxicity assay for anticancer drug screening. J Nat Cancer Inst 1990; 82: 1107-1112.

16. Zhang DZ, Li X. Studies on the aromatic constituents from Artemisa sacrorum Ledeb. Chin Tradit Herb Drug 1993; 24: 283-288

17. Zhang DZ, Li X, Zhu YR. Study on the chemical constituents of Artemisa sacrorum Ledeb. J Shen Pharm Univ 1990; 6: 146-148.

18. Wang QH, Wu JS, Wu RJ, Han NRCKT, Dai NYT. Two new flavonoids from Artemisa sacrorum Ledeb and their antifungal activity. J Mol Struc 2015; 1088: 34-37.

19. Zhang XD, Ni W, Yan H. Two new phenolic compounds from Artemisia iwayomogi. Chem Biod 2014; 11: 760-766.

20. Arunce S, Kaoruu, HiroshiI. Identification of a new angiotensin-converting enzyme (ACE) inhibitor from Thaiedible plants. Food Chem 2014; 165: 92-97.

21. Wang QH, Wu RJ, Han NRCKT, Dai NYT, Wu JS. Two new compounds from Artemisa sacrorum Ledeb. Nat Prod Commun 2016; 11: 489-490.

22. Tanaka T, Nakashima T, Ueda T. Facile discrimination of aldose enantiomers by reversed-phase HPLC. Chem Pharm Bull 2007; 55: 899-901.

23. Gluckman PD. Epigenetic mechanisms that underpin metabolic and cardiovascular diseases. Nat Rev Endocrinol 2009; 5: 401-408.

24. Gurusamy N, Ray D, Lekli I, Das DK. Red wine antioxidant resveratrol-modified cardiac stem cells regenerate infracted myocardium. J Cell Mol Med 2010; 14: 2235-2239.

25. Ndiaye M, Philippe C, Mukhtar H, Ahmad N. The grape antioxidant resveratrol for skin disorders: Promise, prospects, and challenges. Arch Biochem Biophys 2011; 508: 164-170.

26. Busquets S, Ametller E, Fuster G, Olivan M, Raab V. Resveratrol, a natural diphenol, reduces metastatic growth in an experimental cancer model. Cancer Lett 2007; 245: 144-148.

\section{*Correspondence to}

Qinghu Wang

College of Traditional Mongolian Medicine

Inner Mongolia University for Nationalities

PR China 